\title{
Työyhteisö tukee suomen kielen oppimista siivoustyössä
}

\begin{abstract}
Maiju Strömmer: Mahdollisuuksien rajoissa. Neksusanalyysi suomen kielen oppimisesta siivoustyössä. Jyväskylä Studies in Humanities 336. Jyväskylä: Jyväskylän yliopisto 2017. 118 s. + neljä artikkelia. ISBN 978-951-39-7264-6.
\end{abstract}

Maiju Strömmerin väitöskirja Mahdollisuuksien rajoissa: Neksusanalyysi suomen kielen oppimisesta siivoustyössä käsittelee siivoustyössä toimivien maahanmuuttajien suomen kielen oppimista neljän osatutkimuksen pohjalta. Osatutkimukset on nivottu yhteen neksusanalyyttisen tutkimusstrategian pohjalta (mm. Scollon 2001a, 2001b; Scollon \& Scollon 2003, 2004).

Kielenoppiminen nähdään työssä ekologisesta näkökulmasta osallistumisena merkitykselliseen toimintaan (ks. van Lier 2000, 2004, 2007), joka tässä tapauksessa liittyy työpaikalla esiin nouseviin kielellisiin ja ammatillisiin tarpeisiin. Suomen kielen oppimista tarkastellaan työssä tarjoutuvien mahdollisuuksien ja rajoitusten, työyhteisön tuen ja kielen oppimiseen investoimisen kannalta.

Tiivistän seuraavassa ensin keskeiset periaatteet neksusanalyysista tutkimusstrategiana ja näkökulmana sosiaalisen toiminnan tarkasteluun. Seuraavaksi esittelen väitöskirjan osatutkimukset. Lopuksi arvioin väitöskirjan kokonaisuutta esimerkkinä neksusanalyyttisesta tutkimuksesta.

\section{Neksusanalyysi tutkimusstrategiana}

Neksusanalyysi on luonteeltaan etnografinen, osallistuva tutkimusstrategia, jossa yhdistyvät usean tutkimusperinteen juonteet - muun muassa lingvistinen ant- ropologia, kriittinen diskurssianalyysi ja vuorovaikutuslingvistiikka sekä kulttuurihistoriallinen näkemys sosiaalisesta toiminnasta. Alkusysäyksen alalle antoivat Ron Scollon ja Suzy Wong Scollon ja myöhemmin heidän oppilaansa ja kollegansa, kuten Rodney H. Jones ja Sigrid Norris, kehittelemällä näkemystä sosiaalisesta toiminnasta välitteisenä ja historiallisena (ks. Scollon 2001a, 2001b; Scollon \& Scollon 2003, 2004). Tutkimusotetta kutsuttiin välitteisen diskurssin analyysiksi (MDA, mediated discourse analysis). Jatkossa nousi esille MDA:n menetelmällinen puoli vahvemmin neksusanalyysin nimellä ( $N A$, nexus analysis). Tällä hetkellä näkee tutkimusta, jonka tutkijat positioivat joko MDA:ksi tai NA:ksi käyttäen näitä nimityksiä täsmälleen samasta asiasta. Toisaalta monet myös näkevät näiden suhteen kuten Scollon ja de SaintGeorges (2011: 73): MDA tarjoaa linssin sosiaalisen toiminnan luonteeseen, ja NA puolestaan toimii MDA:n historiallisena, etnografisena ja metodologisena ulottuvuutena. Strömmerin tutkimuksessa MDA:n ja NA:n suhde on määritelty ikään kuin näiden ajattelutapojen väliltä: molempien nähdään tarjoavan menetelmällisiä vaihtoehtoja, mutta välitteisen diskurssin analyysin ajatellaan olevan neksusanalyysin multimodaalisuutta ja materiaalisuutta tarkasteleva suuntaus (ks. s. 54). Seuraavassa käytän neksusanalyysi-termiä viittaamaan edellä mainittuun teoreettis-metodologiseen näkökulmaan kokonaisuutena.

Neksusanalyysissa tarkastelun kohteena ei Scollonin ja Scollonin (2004) mukaan ole pelkästään kieli, vaikka kielentutkimus olisikin kyseessä, vaan sosiaalinen toiminta, joka toteutuu tiettynä ai- 
kana tietyssä paikassa tiettyjen osallistujien kesken. Katse ei kuitenkaan kohdistu vain tilanteiseen vuorovaikutukseen kuten keskustelunanalyysissa, vaan toimintaan historiallisena prosessina. Osallistujilla on kullakin oma kokemushistoriansa (historical body), jonka pohjalta he rakentavat suhdettaan toisiin osallistujiin, keskinäistä vuorovaikutusjärjestystään (interaction order). Tietyssä ajassa ja paikassa reaalistuvat ja uusiutuvat osallistujien esiin nostamat diskurssit (discourses in place), mutta myös ajallisesti kaukaisempien toimijoiden ääni voi nousta merkitykselliseksi. Esimerkiksi kaupungin valoristeys on monen regulatiivisen, säätelevän diskurssin kohtauspaikka. Jalankulkija seuraa liikennemerkkejä ja -valoja sekä katuun maalattuja värikoodeja mutta myös toisten kehollista toimintaa. Elämän varrella on muun muassa kasvattajilta opittu, miten liikenteessä tulee edetä muita kunnioittaen.

Neksusanalyysia tehdessään tutkija lähtee liikkeelle hankkiutumalla itse mahdollisimman lähelle tutkittavaa toimintaa, joko osallistujana tai ainakin selvittämällä itselleen oman suhteensa siihen (Scollon \& Scollon 2004: 83). Toimintaan liittyviä tekijöitä havainnoidaan, kartoitetaan ja rajataan kysymällä, ketkä ovat siihen liittyvät avainhenkilöt ja keskeiset diskurssit. Tutkija myös tunnistautuu tutkijaksi ja tarkastelee omaa suhdettaan toimintaan (engaging the nexus of practice). Scollon ja Scollon (mts. 9) pitävät tärkeänä sitä, että tutkija ei jää analysoimaan vain tilanteita sinänsä vaan laajentaa tarkastelun piiriä. Kun tutkimuksen kohdetta on saatu täsmennettyä, tutkija navigoi eli raivaa tietään eteenpäin analysoimalla syvällisemmin ajallisella jatkumolla osallistujien polkuja, toiminnalle tyypillisiä paikkoja, tilanteita, resursseja sekä näihin liittyviä semioottisia syklejä (navigating the nexus of practice). Neksusanalyyttisellä tutkimuksella on usein lähtökohtana muutoksen tuottaminen (changing the nexus of prac- tice). Kriittisen diskurssianalyysin tapaan se pyrkii paikantamaan yhteiskunnallisia epäkohtia ja vaikuttamaan niihin. Neksusanalyysi lähtee myös siitä, että tutkija saa jotain muutosta liikkeelle jo silloin, kun hän tunnistautuu tutkijaksi ja asettuu osaksi yhteisöä (mts. 152).

\section{Osatutkimukset}

Strömmerin väitöskirjan ensimmäisessä osatutkimuksessa (Partanen 2013) tarkastelu kohdistui kolmen puhdistuspalvelualalla työskentelevän maahanmuuttajan käsityksiin ja kokemuksiin vieraan kielen eli tässä tapauksessa suomen oppimisesta työssä. Tutkimusaineisto kerättiin jokaiselta osallistujalta kahdesti puolistrukturoidun teemahaastattelun avulla. Aineiston analyysia tekijä luonnehtii laajasti ottaen laadulliseksi sisällönanalyysiksi, jossa hän hyödynsi muun muassa dialogista näkökulmaa (Bakhtin 1981 [1934-1935]; Wertsch 1998; Aro 2009). Tutkimus tuo esiin sen, kuinka haastateltavien kielenkäyttö ja kielenoppimisen tarpeet liittyivät kiinteästi fyysisten työtehtävien suorittamiseen. Suomen kielen käytön mahdollisuudet työn yhteydessä osoittautuivat rajallisiksi, sillä työntekijät käyttivät keskinäisessä vuorovaikutuksessaan englantia eikä asiakasorganisaation työntekijöiden kanssa syntynyt juurikaan vuorovaikutusta. Suomen oppimista mahdollistavia diskursseja olivat erilaiset työntekoon liittyvät työohjeet, tiedotteet ja ilmoitukset. Nämä mahdollisuudet oppia kieltä olivat vahvasti sidoksissa työyhteisön tarjoamaan tukeen. Kuten tekijä toteaa, varsinkin alkuvaiheen kielenoppijoille nämäkin tarjoumat voivat olla toimivia, jos työkielenä on suomi ja oppijoita tuetaan työtehtävien ymmärtämisessä.

Toisessa osatutkimuksessa (Strömmer 2016a) tarkasteluun valittiin erityisesti yhden työntekijän, niin sanotun avainosallistujan eli tutkittavan toiminnan kan- 
nalta tyypillisen toimijan näkökulma: miten hän luo ja käyttää suomen kielen oppimisen mahdollisuuksia työssään (mm. työtilanteissa rakentuva vuorovaikutusjärjestys, ks. Goffman 1983). Aineistoa kertyi monipuolisesti: tutkijan havaintoja ja äänitallenteita työtä seuratessa, valokuvia, kenttämuistiinpanoja sekä työntekijän ja hänen esimiehensä haastatteluja. Vaikka tarjoumat suomen oppimiselle olivat tässäkin työpaikassa niukat, tutkimukseen osallistumisen myötä siivousohjaaja ja esimies alkoivat käyttää työntekijän kanssa enemmän suomen kieltä englannin sijasta. Tutkijan läsnäolo työpaikalla vahvisti myös työntekijän tietoisuutta työympäristön kielimaailman tarjoumista suomen oppimiselle (mm. kyltit ja tiedotteet). Neksusanalyysiin sisältyvä muutoksen ajatus tuli esiin konkreettisesti, kun tutkimuksen teko ja tutkijan osallisuus tutkittavassa toiminnassa muuttivat osallistujien välisiä suhteita (vuorovaikutusjärjestys) ja työyhteisön toimintatapoja.

Kolmas osatutkimus (Strömmer 2016b) kohdistui materiaalisen oikea-aikaisen tuen merkitykseen suomen kielen oppimiselle työtilanteissa. Tällä tarkoitetaan muun muassa työtehtävistä selviytymiseen tarvittavia kielelliseen toimintaan kietoutuvia resursseja kuten ohjeita sekä eleitä, ilmeitä ja kehonkieltä (ks. s. 32). Kahdesta työkohteesta kerättiin moninaista aineistoa kuten havaintomuistiinpanoja, äänija videotallenteita, haastatteluja ja valokuvia. Materiaalisen tuen yhteistoiminnallisen rakentamisen tarkastelussa käytettiin Norrisin (2004) jäsennystä. Se kuvaa välitteisen diskurssin näkemyksen pohjalta multimodaalisen analyysin keskeistä jäsennystä, jonka avulla sosiaalinen toiminta nähdään usean osatoiminnan kokonaisuutena (higher-level action, lower-level action). Materiaaliset artefaktitkin voidaan tulkita menneen sosiaalisen toiminnan jähmettyneiksi tuotteiksi (frozen action), joihin on tiivistynyt muun muassa tekijöiden käytänteitä ja käsityksiä (esim. vanhan ajan luokkahuone). Tutkimus lisäsi ymmärrystä siitä, miten työpaikan semioottinen varanto (semiotic budget, ks. van Lier 200o) voi olla eri tilanteissa ja tiloissa joko monipuolinen tai rajallinen kielen käytön ja oppimisen resurssi silloin, kun tukea tarvitaan. Tällaisia resursseja voivat olla esimerkiksi kielellisten artefaktien tarjoaminen sekä multimodaalinen vuorovaikutus kollegojen kanssa.

Väitöskirjan viimeinen osatutkimus on mukana teoksessa käsikirjoituksena, mutta se julkaistiin heti väittelyn jälkeen (Strömmer 2017). Sen aineistoa ovat kahden työntekijän kertomukset omasta suomen kielen oppimisen kehityskaarestaan. Tarkastelun kohteena on yhtäältä se, kuinka paljon he käyttivät aikaa ja energiaa suomen kielen oppimiseen, toisaalta se, miten heidän oppimiseensa panostettiin eri konteksteissa, esimerkiksi koulutuksessa ja työpaikalla (investment, ks. Norton 1995; Darvin \& Norton 2015). Osallistujien kertomuksia analysoitiin pienten tarinoiden (small stories) sekä positioinnin näkökulmasta (Georgakopoulou 2006; Bamberg 2004; Bamberg \& Georgakopoulou 2008). Tutkimus tuo esiin osallistujien erilaiset polut maahantulon jälkeen ammatillisessa orientoitumisessa ja siihen kytkeytyvässä suhtautumisessa suomen kielen oppimiseen. Tutkimus myös osoittaa, kuinka kielen oppimiseen panostaminen voi olla merkityksellistä, kun se on linjassa ammatillisten tavoitteiden kanssa. Toisaalta suomen kielen oppimisen mahdollisuudet voivat olla työntekijälle hyvinkin rajalliset työpaikalla, elleivät työyhteisö ja työnantajat siihen panosta.

\section{Väitöskirjan kokonaisuus neksus- analyyttisena tutkimuksena}

Neksusanalyysia on kehitelty tutkimusstrategiana enemmän vasta parin vuosikymmenen ajan eri tieteenaloilla. Alan tutkimusperinne on siis vielä varsin nuori, ja eritaustaiset tutkijat voivat to- 
teuttaa tutkimusta hyvin erilaisin painotuksin. Kielen oppimisen tarkastelussa neksusanalyysia on sovellettu varsin vähän. Kaiken kaikkiaan tiedeyhteisön konventiot raportoida neksusanalyyttista tutkimusta ovat vasta muotoutumassa. Tekijä toteaakin, että tällaisen tutkimuksen tulosten kirjoittaminen voi olla haasteellista (ks. s. 89). Tämä johtunee osin siitä, että sosiaalisen toiminnan eri aspektit - osallistujien kokemushistoria, vuorovaikutusjärjestys ja paikan diskurssit - kytkeytyvät toisiinsa kiinteästi ja dynaamisesti eri tilanteissa. Toisaalta tutkimusstrategian kolme tehtävää - kartoitus, navigointi ja muutos - näyttäytyvät osin toisiaan seuraavina, mutta myös päällekkäisinä toistuvina prosesseina. Tutkimusraportin laadinnassa siis lineaarinen esitystapa taistelee ilmiön monimuotoisuutta ja dynaamisuutta vastaan.

Tekijä on kuitenkin onnistunut rakentamaan väitöskirjan mainiosti siten, että artikkeleissa raportoidut osatutkimukset sekä niitä kokoavassa ja arvioivassa osuudessa käsitellyt aiheet muodostavat koherentin kokonaisuuden. Hän on asemoinut tutkimuksensa tieteen kentälle hyvin ja perustellut omat neksusanalyyttiset painotuksensa. Ensimmäisessä artikkelissa neksusanalyysi ei ole vielä näkyvissä, mutta tekijä on tutkimuksen edetessä kytkenyt sen luontevasti osaksi tutkimusasetelmaa. Neksusanalyyttinen tutkimusstrategia nivoo yhteen osallistujien vuorovaikutusjärjestykset ja kokemukset sekä tilanteiset diskurssit ja tuottaa näin suomen kielen oppimisesta siivoustyössä kompleksisen kuvan. Tutkimus tarjoaa ymmärrystä yksittäisen kielenoppijan tilanteesta mutta myös kielikoulutuksen yhteiskunnallisista ulottuvuuksista.

Tutkimus on kokonaisuutena innovatiivinen, ja se on edellyttänyt tutkijalta pitkäjänteistä työtä myös osallistujien työpaikalla. Aineistoarkisto sisältää lukuisia ääni- ja videotallenteita esimerkiksi haastatteluista ja työtilanteista sekä havainto- muistiinpanoja, joita tukee laaja valokuvakokoelma kentältä. Tutkija on pohtinut monipuolisesti tutkimuksen eettisiä näkökulmia, jotka liittyvät muun muassa tutkittavien asemaan, tutkijan rooliin ja tulkintoihin. Ratkaisut ovat olleet onnistuneita, ja analyysi osoittaa kaiken kaikkiaan valitun tutkimusotteen hyvää hallintaa. Tutkittavan ilmiön etnografinen kuvaus on erityisen ansiokas, sillä se valottaa suomen kielen oppimisen eri ulottuvuuksia henkilökohtaisista tarinoista laajempiin sosiopoliittisiin näkymiin, mikä onkin neksusanalyysin kannalta tärkeää. Artikkeleissa esitetyt analyysit ovat yksityiskohtaisia ja oivaltavia, ja tulkintoja on havainnollistettu runsain aineistoesimerkein. Tutkimuksen tulokset on punnittu asiantuntevasti suhteessa työn teoreettiseen viitekehykseen, joskin neksusanalyysin keskeisiä käsitteitä olisi voinut hyödyntää johtopäätösten esittelyssä vahvemminkin.

Väitöskirjatutkimus tuottaa uutta tietoa ja tarjoaa sovellusalueita paitsi suomi vieraana kielenä -opetukselle ja työelämän kielikoulutukselle myös minkä tahansa kielen (koulu)opetukselle korostamalla kielenoppimisen luonnetta yhteisöllisesti tuettuna merkityksellisenä ja tavoitteellisena toimintana. Neksusanalyysin nuoren ja kirjavan perinteen jatkajana tällä väitöstutkimuksella on tärkeä merkitys erityisesti kielentutkimuksen ja kielenoppimisen tutkimuksen kentällä.

$$
\begin{array}{r}
\text { LEENA KUURE } \\
\text { etunimi.sukunimi@oulu.fi }
\end{array}
$$

Kirjoittaja on englantilaisen filologian yliopistonlehtori Oulun yliopistossa. Hän toimi Strömmerin vastaväittäjänä.

\section{Lähteet}

Aro, MARI 2009: Speakers and doers. Polyphony and agency in children's beliefs 
about language learning. Jyväskylä Studies in Humanities 116. Jyväskylän yliopisto.

Bakhtin, Minail 1981 [1934-1935]: The dialogic imagination. Four essays by M. M. Bakhtin. Kääntäneet Caryl Emerson \& Michael Holquist. Austin, TX: University of Texas.

BAmberg, Michael 2004: Talk, small stories, and adolescent identities. - Human Development 47 s. 366-369. https://doi. org/10.1159/000081039.

Bamberg, Michael - GeorgakopouLOU, AlEXANDRA 2008: Small stories as a new perspective in narrative and identity analysis. - Text and Talk 28 s. 377-396. https://doi.org/10.1515/ TEXT.2008.018.

Darvin, Ron - Norton, Bonnie 2015: Identity and a model of investment in applied linguistics. - Annual Review of Applied Linguistics 35 s. 36-56. https:// doi.org/10.1017/So267190514000191.

Georgakopoulou, Alexandra 2006: Thinking big with small stories in narrative and identity analysis. - Narrative Inquiry 16 s. 122-130. https://doi. org/10.1075/ni.16.1.16geo.

GoffMAn, ERvin 1983: The interaction order. - American Sociological Review 48 s. 1-17. https://doi.org/10.2307/2095141.

VAN LIER, LEO 2000: From input to affordance. Social-interactive learning from an ecological perspective. - James P. Lantolf (toim.), Sociocultural theory and second language learning s. 245-260. Oxford: Oxford University Press.

- 2004: The ecology and semiotics of language learning. Dordrecht: Kluwer Academic Publishers.

_ 2007: Action-based teaching, autonomy and identity. - Innovation in Language Learning and Teaching 1 s. 46-65. https:// doi.org/10.2167/illt42.o.

Norris, Sigrid 2004: Multimodal discourse analysis. A conceptual framework. Philip LeVine \& Ron Scollon (toim.),
Discourse \& technology. Multimodal discourse analysis s. 101-115. Washington D.C.: Georgetown University Press.

Norton, Bonny P. 1995: Social identity, investment, and language learning. TESOL Quarterly 29 s. 9-31. https://doi. org/10.2307/3587803.

Partanen, Maiju 2013: Suomen kielen oppimisen mahdollisuudet ja työyhteisön tuki puhdistuspalvelualalla. Afrikkalaisten maahanmuuttajien käsityksiä ja kokemuksia. - Tiina Keisanen, Elise Kärkkäinen, Mirka Rauniomaa, Pauliina Siitonen \& Maarit Siromaa (toim.), Osallistumisen multimodaaliset diskurssit s. 55-76. Suomen soveltavan kielitieteen yhdistyksen julkaisuja 71. Jyväskylä: Suomen soveltavan kielitieteen yhdistys AFinLA.

Scollon, Ron 2001a: Action and text. Towards an integrated understanding of the place of text in social (inter-)action, mediated discourse analysis and the problem of social action. - Ruth Wodak \& Michael Meyer (toim.), Methods in critical discourse analysis s. 139-189. London: Sage.

_ 2001b: Mediated discourse. The nexus of practice. New York: Routledge.

Scollon, Ron - Scollon, Suzy W. 2003: Discourses in place. Language in the material world. New York: Routledge.

- 2004: Nexus analysis. Discourse and the emerging internet. London: Routledge.

Scollon, Suzy W. - De SAint-Georges, INGRID 2011: Mediated discourse analysis - James Paul Gee \& Michael Handford (toim.), The Routledge handbook of discourse analysis s. 66-78. London: Routledge.

Strömmer, MAiju 2016a: Affordances and constraints. Second language learning in cleaning work. - Multilingua. Journal of Cross-Cultural and Interlanguage Communication 35 s. 697-721. https://doi. org/10.1515/multi-2014-0113.

_ 2016b: Material scaffolding. Supporting 
the comprehension of migrant cleaners at work. - European Journal of Applied Linguistics 4 s. 239-275. https://doi. org/10.1515/eujal-2015-0039.

- 2017: Work-related language learning trajectories of migrant cleaners in
Finland. - Apples. Journal of Applied

Language Studies 11 (4) s. 137-16o.

https://doi.org/10.17011/apples/

urn.201712214863.

Wertsch, James 1998: Mind as action.

Oxford: Oxford University Press.

\section{Mikael Agricolan yhteen kirjoittamien yhdyssanojen rakenteen kuvausta}

Tanja Toropainen: Yhdyssanat ja yhdyssanamaiset rakenteet Mikael Agricolan teoksissa. Turun yliopiston julkaisuja C 439. Turku: Turun yliopisto 2017. Johdanto 85 s. (+ liitteet 37 s.) ja viisi artikkelia 120 s. ISBN 978-951-29-6874-9.

Tanja Toropainen tarkastelee artikkeliväitöskirjassaan Mikael Agricolan yhdyssanoja tavoitteenaan kuvata Agricolan käyttämät yhdyssanojen rakennetyypit, selvittää yhdyssanarakenteiden alkuperää ja vakiintumista sekä arvioida yhdyssanan käsitettä vanhan kirjakielen aineiston pohjalta.

Väitöskirja koostuu viidestä artikkelista (Vaittinen 2003, 2007; Toropainen 2014, 2015, 2016) ja yhteenvedosta. Artikkeleista yksi on ilmestynyt Virittäjässä, muut on julkaistu Sananjalassa. Artikkeleissa käsitellään 1) yhdysverbejä, 2) yhdysadjektiiveja, 3) ylen-alkuisia yhdyssanoja, jotka voivat olla verbejä, substantiiveja, adjektiiveja tai adverbeja, 4) adjektiivialkuisia, kongruoivia yhdyssubstantiiveja ja 5) typografian vaikutusta yhdyssubstantiivien yhteen kirjoittamiseen Agricolan teoksissa. Väitöskirjan laajassa yhteenvedossa on täydennetty artikkeleista syntyvää kuvaa ja esitelty Agricolan yhdyssanojen rakennetyypit sanaluokittain käyttämällä koko pitkän prosessin aikana kertynyttä aineistoa. Yhteenvedossa esitetty kuvaus on täydentynyt erityisesti yhdyssubstantiivien osalta. Yhteenveto on huomattavan pitkä, ilman liitteitä 85 sivua, mikä ylittää selvästi sille asetetun suosituspituuden (Turun yliopistossa 50 s.). Kolme liitettä (yht. 37 s.) esittelevät väitöskirjaaineiston kokonaisuudessaan.

\section{Mikä on yhdyssana?}

Nykyisin suomen kirjakielessä yhdyssanan tunnistaa siitä, että sen osat on kirjoitettu yhteen (ks. esim. Koivisto 2013: 329). Yhdyssanojen yhteen ja erilleen kirjoittamisen vakiintuminen nykyisenkaltaiseksi on kuitenkin vaatinut pitkän ajan. Kuten väitöskirjan yhteenvedossakin todetaan (s. 24-25), vanhimmissa suomen kieliopeissa yhteen kirjoittamista ei vielä pidetty yhdyssanojen tuntomerkkinä. Kirjasuomen ensimmäisinä vuosisatoina ortografia oli monin tavoin horjuvaa; yhdyssanojen osalta se tarkoitti yhteen ja erikseen kirjoittamisen vakiintumattomuutta. Toropaisen tutkimusasetelma on haastava, koska voidaan kysyä, onko Agricolan yhdyssanoja tai muita varhaisia 